\title{
Based Cluster Analysis For Network Group Events
}

\author{
Chen Wan \\ College of Economics and Management \\ Hebei University of Science and Technology \\ Shijiazhang,Hebei, China \\ e-mail:121wanchen@163.com
}

\begin{abstract}
The paper select the 20 hotest network events in 2013 as the research sample from the opinion monitoring room of People.It made the cluster analysis from the angle of these incidents to explore the characteristics,connotations and demands of the events. Research shows that the overall 2013 network group events focused on the perspective of social justice. Most Internet users have been spun off following the thread of the network blindly in the past and put forward their views and opinions through the understanding of events, actively and effectively participating in the discussion of the network. Internet medias become a tool to express the will of ordinary people This reflects the improved quality of Internet users, and correspondingly the government administrators need to have a higher requirements. The fact that traditional media coverage after the event is more likely to cause network public opinion, which requires the effective integration of traditional media and online media networks to prevent the outbreak of mass incidents.
\end{abstract}

Keywords- network group events ; network media ; cluster analysis; instrumentalization;effective combination

\section{INTRODUCTION}

In 2013, the plate of the network public opinion has an obvious change. The Government has increased the intensity of Internet governance, the development of weibo, blogs and news client have made the mobile Internet become new channels to obtain hot spot for people. More and more people are no longer just recipients of information dissemination. They become participants in the process of the information dissemination. Internet users express their views through the convenient channels, among them are some discordant voices, which requires the governments and the media effectively guide. If the governments and the media do not control the network of public opinion trends, it may lead to the outbreak of the network group events.

August 19, 2013, Xi Jinping,the General Secretary at the national conference on publicity and ideological suggested that the Internet has become the main battlefield of public opinion. Many people, especially young people basically do not see the mainstream media, most of the information is obtained from the Internet.. Online media should work as the most important task of propaganda and ideological work. This paper concerns the public hotspot network event occurred in 2013 using of cluster analysis method. By classifying the hot events of network of public opinion on this year's, it can provide references and recommendations for the next network media approaches.

\section{DATA SOURCES, VARIABLE SELECTION AND THE METHOD}

\section{A. The Study Sample}

Because the frequency of incidents of the network of public opinion is increasingly high in recent years, many media will selected the annual network event caused widespread concern. What this paper select is published by People's opinion monitoring room "2013 China Internet public opinion analysis report" network public opinion in 20 hotspots occurred from November 1, 2012 to October 31, 2013 as the research sample, as shown in Table I .

TABLE I STUDY SAMPLE

\begin{tabular}{|c|c|c|c|}
\hline No. & Event Name & No. & Event Name \\
\hline 1 & $\begin{array}{c}\text { Xue Manzi arrested on } \\
\text { suspicion of } \\
\text { prostitution incident }\end{array}$ & 11 & $\begin{array}{l}\text { "No waste food } \\
\text { action" }\end{array}$ \\
\hline 2 & Li Moumou case & 12 & $\begin{array}{l}\text { Huangpu River dead } \\
\text { pigs floating event }\end{array}$ \\
\hline 3 & Bo Xilai case & 13 & $\begin{array}{c}\text { Xia Junfeng was } \\
\text { executed event }\end{array}$ \\
\hline 4 & $\begin{array}{c}\text { Snowden "Prism" } \\
\text { incident }\end{array}$ & 14 & $\begin{array}{l}\text { Shenmu "room } \\
\text { sister" event }\end{array}$ \\
\hline 5 & $\begin{array}{c}\text { Lushan earthquake } \\
\text { Xiamen bus fire } \\
\text { incident }\end{array}$ & 15 & $\begin{array}{c}\text { "Southern Weekend" } \\
\text { event }\end{array}$ \\
\hline 7 & $\begin{array}{c}\text { Shanghai Justice } \\
\text { Collective prostitution } \\
\text { incident }\end{array}$ & 17 & $\begin{array}{c}\text { Hainan Wanning } \\
\text { Principals open house } \\
\text { event }\end{array}$ \\
\hline 8 & $\begin{array}{c}\text { Farmer spring"quality } \\
\text { gates" }\end{array}$ & 18 & $\begin{array}{c}\text { Gansun junior high } \\
\text { school students were } \\
\text { arrested event }\end{array}$ \\
\hline 9 & $\begin{array}{c}\text { Zeng ChengJie death } \\
\text { penalty case }\end{array}$ & 19 & $\begin{array}{c}\text { Luo Changping real } \\
\text { name Liu Tienan } \\
\text { event }\end{array}$ \\
\hline 10 & $\begin{array}{c}\text { Express reporter Chen } \\
\text { Yongzhou been } \\
\text { arrested event }\end{array}$ & 20 & $\begin{array}{c}\text { Hong Kong "limit } \\
\text { order milk" incident }\end{array}$ \\
\hline
\end{tabular}

B. The index selection, data sources and processing

Network group events generally originated in the cause of public concern topics/events.It's evolved by discussions 
between users and the effective interaction with traditional media through the Forum,blog,microblogging, portals ,other new media platforms and the traditional topics / events have a direct impact on real life, the medias .Especially traditional media can promote the

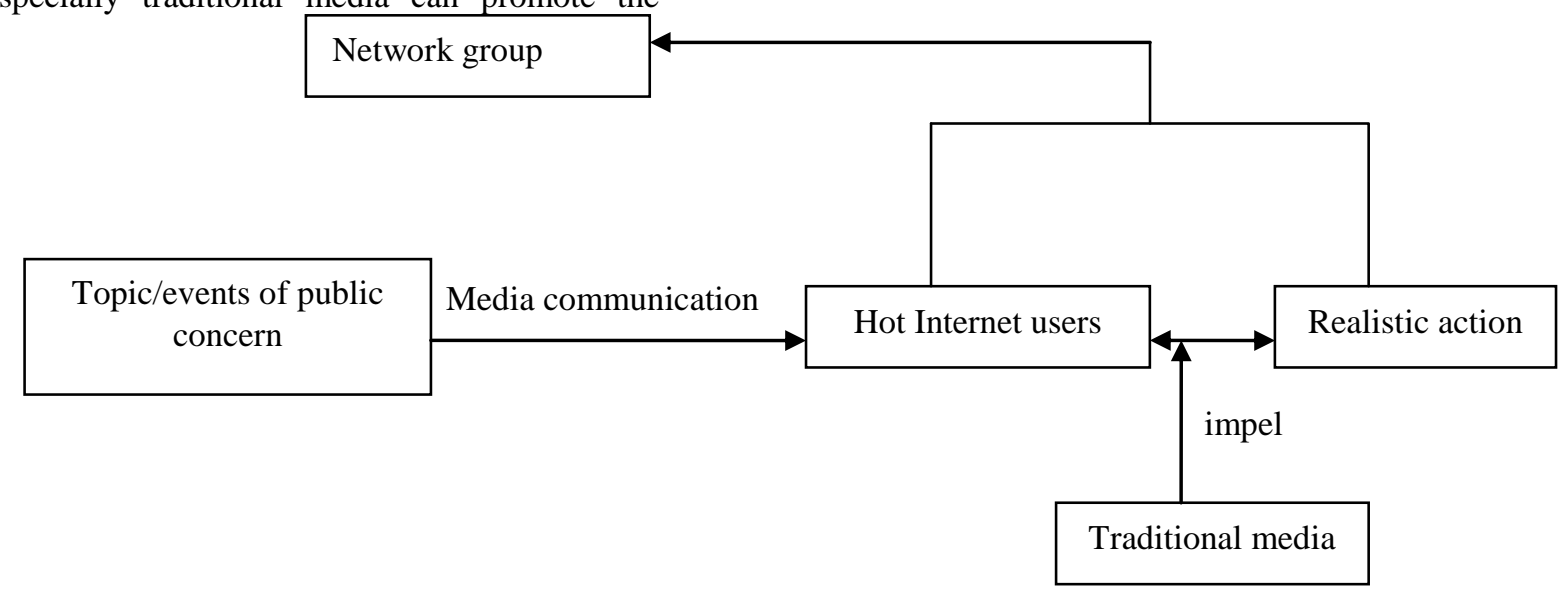

Figure 1. Network group events occurred procession

Table II CLUSTER DEFINITION AND DESCRIPTION

\begin{tabular}{|c|c|c|c|}
\hline $\begin{array}{l}\text { Phase } \\
\text { occurs }\end{array}$ & Index & $\begin{array}{l}\text { Analytical } \\
\text { indicators }\end{array}$ & Explanation \\
\hline Source & $\begin{array}{l}\text { Events } \\
\text { reasonB1 }\end{array}$ & $\begin{array}{c}\text { Who set the } \\
\text { agenda }\end{array}$ & $\begin{array}{c}\text { Dummy } \\
\text { variables, } \\
\text { traditional } \\
\text { media is } 0 \text {, } \\
\text { new media } \\
\text { is } 1\end{array}$ \\
\hline Content & $\begin{array}{l}\text { Correlationm } \\
\text { with } \\
\text { netizensB2 }\end{array}$ & $\begin{array}{c}\text { Individual } \\
\text { event itself } \\
\text { is associated } \\
\text { users }\end{array}$ & $\begin{array}{c}\text { Dummy } \\
\text { variables, } \\
\text { YES is } 0, \\
\text { NO is } 1\end{array}$ \\
\hline \multirow[t]{3}{*}{ Process } & $\begin{array}{l}\text { The degree of } \\
\text { concern of } \\
\text { Internet } \\
\text { usersB3 }\end{array}$ & $\begin{array}{l}\text { Posting } \\
\text { volume }\end{array}$ & $\begin{array}{c}\text { Continuous } \\
\text { variables }\end{array}$ \\
\hline & $\begin{array}{l}\text { Mainstream } \\
\text { media } \\
\text { attentionB4 }\end{array}$ & $\begin{array}{l}\text { CCTV, } \\
\text { People's } \\
\text { Daily is } \\
\text { concerned }\end{array}$ & $\begin{array}{c}\text { Dummy } \\
\text { variables, } \\
\text { YES is } 0, \\
\text { NO is } 1\end{array}$ \\
\hline & ActionB5 & $\begin{array}{l}\text { Are there } \\
\text { realistic } \\
\text { action } \\
\text { netizens } \\
\text { participation }\end{array}$ & $\begin{array}{c}\text { Dummy } \\
\text { variables, } \\
\text { YES is } 0, \\
\text { NO is } 1\end{array}$ \\
\hline Influence & $\begin{array}{c}\text { Public } \\
\text { decision- } \\
\text { makingB6 }\end{array}$ & $\begin{array}{c}\text { Whether the } \\
\text { Government } \\
\text { has adopted } \\
\text { policies }\end{array}$ & $\begin{array}{r}\text { Dummy } \\
\text { variables, } \\
\text { YES is 0, } \\
\text { NO is } 1\end{array}$ \\
\hline
\end{tabular}

According to the process of the network group incidents occurred, the paper selected six clusters indicators to reflects source, content, process and impact, as shown in Table II. After studying the 20 cases in Table I , the corresponding data is shown in Table III. Using zscore standardized methods for data processing, this method is based on the mean and standard deviation of the original data to standardize the data.

In this paper, 20 network group events conducted Qtype cluster analysis. This paper select Between-groups Linkage which is he distance between the two subcategories within two subcategories average distance between all samples, and Squared Euclidean Distance which is the square of the difference between the value of each sample and each variable.

\section{THE RESULTS}

\section{A. Cluster analysis}

Table III EACH CASE OF BASIC DATA

\begin{tabular}{|c|c|c|c|c|c|c|}
\hline & B1 & B2 & $\begin{array}{c}\text { B3(Unit: } \\
\text { ten } \\
\text { thousand) }\end{array}$ & B4 & B5 & B6 \\
\hline A1 & 0 & 1 & 4787 & 1 & 0 & 1 \\
\hline A2 & 0 & 1 & 1555 & 1 & 0 & 0 \\
\hline A3 & 0 & 1 & 836 & 1 & 0 & 0 \\
\hline A4 & 0 & 1 & 564 & 1 & 0 & 0 \\
\hline A5 & 0 & 0 & 558 & 1 & 1 & 0 \\
\hline A6 & 1 & 0 & 424 & 1 & 0 & 0 \\
\hline A7 & 1 & 0 & 326 & 1 & 0 & 0 \\
\hline A8 & 0 & 0 & 292 & 1 & 1 & 0 \\
\hline A9 & 1 & 1 & 281 & 1 & 0 & 0 \\
\hline A10 & 0 & 1 & 243 & 1 & 0 & 0 \\
\hline A11 & 1 & 0 & 233 & 1 & 1 & 1 \\
\hline A12 & 1 & 0 & 228 & 1 & 1 & 0 \\
\hline A13 & 0 & 1 & 179 & 1 & 0 & 0 \\
\hline A14 & 1 & 0 & 154 & 1 & 0 & 0 \\
\hline A15 & 0 & 1 & 134 & 1 & 0 & 0 \\
\hline A16 & 0 & 0 & 92 & 1 & 1 & 0 \\
\hline A17 & 0 & 1 & 29 & 1 & 1 & 0 \\
\hline A18 & 1 & 1 & 16 & 1 & 0 & 0 \\
\hline A19 & 1 & 1 & 4 & 1 & 0 & 0 \\
\hline A20 & 0 & 0 & 3 & 1 & 1 & 1 \\
\hline & & & & & & \\
\hline
\end{tabular}


This paper uses SPSS17.0 software for post-processing of the data in Table III of the cluster analysis to get cluster tree diagram (Figure II).

\section{B. Type of network group incidents}

According to the correlation matrix, the paper thinks four types is more appropriate, then the value of each part of the main characteristics are shown in Table IV.

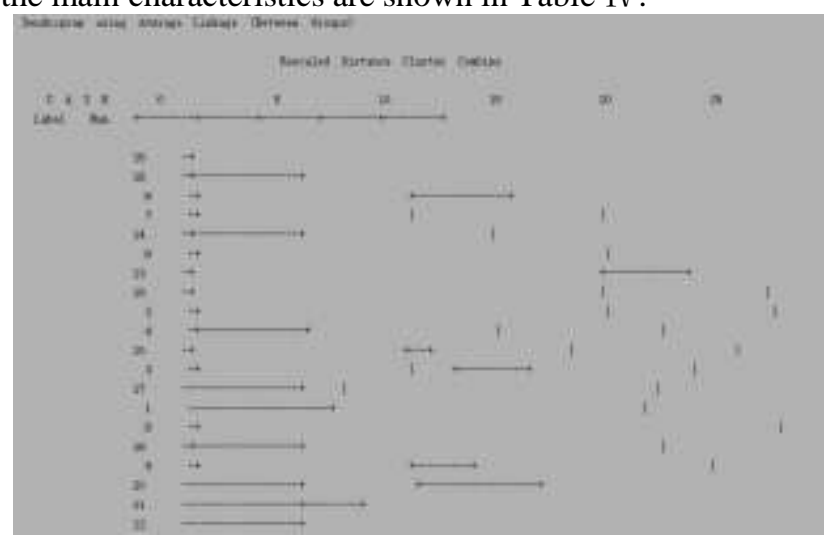

Figure 2. Clustering tree diagram

. According to the results of cluster analysis, through the specific cases and eigenvalues for further analysis, the network public opinion hot events of 2013 is divided into four, these four networks group events in the target, action-oriented and the impact have significant difference

The first category belongs to users on the sidelines of the event. Such events are associated with a famous person or well-known social phenomenon, not associated with individual users, but there is a strong relationship with the community law system. In such event, the main demands of Internet users is to understand the progress of events, and to examine the fairness of justice. In the "Li Moumou case", "Bo Xilai case", as it involves special populations, most users want to konw the result of the event. If the result of events in line with the vast majority of Internet users expected, the event will be as time goes by slowly fading; If the result of the event did not meet the expected users, it may lead to greater media effects.

The second category is morality events. Such events involves natural disasters or public events, and individual users have a certain relevance, involving morality social phenomena. In the "Lushan earthquake" event, users pay close attention to disaster relief information, although their ability to help the affected people. In the "farmer spring 'quality gates' event', because the farmer spring repeatedly exposed quality issues, and its producers refused to recognize that fully reflects the lack of corporate morality, causing the majority of Internet users angry .This shows that the test can cause an event of morality often caused widespread concern of Internet users.

Table IV FOUR NETWORK GROUP INCIDENT MAJOR S EIGENVALUES

\begin{tabular}{|c|c|c|}
\hline Category & Event Name & The main characteristic value \\
\hline \multirow[t]{8}{*}{1} & $\begin{array}{c}\text { Xue Manzi arrested on suspicion of prostitution } \\
\text { incident }\end{array}$ & \multirow{8}{*}{$\begin{array}{l}\text { Traditional media is the agenda } \\
\text { setter, the nature of the event is not } \\
\text { associated with an individual Internet } \\
\text { users, but a great impact on society, the } \\
\text { reality of action without users }\end{array}$} \\
\hline & Li Moumou case & \\
\hline & Bo Xilai case & \\
\hline & Snowden "Prism" incident A4 & \\
\hline & $\begin{array}{c}\text { Express reporter Chen Yongzhou been arrested } \\
\text { event }\end{array}$ & \\
\hline & Xia Junfeng was executed event & \\
\hline & "Southern Weekend" event & \\
\hline & Changchun auto theft and infanticide event & \\
\hline \multirow[t]{4}{*}{2} & Lushan earthquake & \multirow{4}{*}{$\begin{array}{l}\text { Traditional media is the agenda } \\
\text { setter, the nature of the event in terms } \\
\text { of Internet users have a personal } \\
\text { association, a great social impact, there } \\
\text { is the reality of actions users }\end{array}$} \\
\hline & Farmer spring"quality gates" & \\
\hline & Hainan Wanning Principals open house event & \\
\hline & Hong Kong "limit order milk" incident & \\
\hline \multirow[t]{6}{*}{3} & Xiamen bus fire incident & \multirow{6}{*}{$\begin{array}{l}\text { New media is the agenda setter, the } \\
\text { nature of the event is not associated } \\
\text { with an individual Internet users, the } \\
\text { huge social influence, no users practical } \\
\text { action }\end{array}$} \\
\hline & Shanghai Justice Collective prostitution incident & \\
\hline & Zeng ChengJie death penalty case & \\
\hline & Shenmu "room sister" event & \\
\hline & $\begin{array}{c}\text { Gansu junior high school students were arrested } \\
\text { event }\end{array}$ & \\
\hline & Luo Changping real name Liu Tienan event & \\
\hline \multirow[t]{2}{*}{4} & "No waste food action" & \multirow{2}{*}{$\begin{array}{l}\text { New media is the agenda setter, the } \\
\text { nature of events related to individual } \\
\text { users, the big social influence, there is } \\
\text { the reality of actions users }\end{array}$} \\
\hline & Huangpu River dead pigs floating event & \\
\hline
\end{tabular}

The third category is the administrative class.Such an event involved in public official,that is not associated with individual users, but the social impact is extremely poor which often caused the social management of criticism by
users."Shanghai Justice Collective prostitution incident","Shaanxi Shenmu 'room sister' event ', exposing the ugly social thinking of public officials, who used his authority to seek their own interests phenomenon. 
Especially China is in a critical period of social transformation, unfair distribution of social resources makes a lot of people at the bottom of society to such events were too sensitive. Therefore, this more likely to cause such incidents network group events.

The fourth category is involved in social management events. Such events have ralationships with netizens basic daily lives, involving basic necessities of life, whichi is a great correlation with individual users and beneficial for social progress. Internet users through an easy action to complete the proposal, there is a huge social effect. "No waste food action" advocated austerity, opposing extravagance and waste, driving people cherish the food.Users get widely recognized and actively called for the appropriate call, that is widely disseminated on the Internet.

\section{CONCLUSION}

\section{A. People are increasingly concerned about social justice}

From the above data analysis concluded, the focus of attention is increasingly focused on users of social fairness. The events involving special populations tend to be more prone to online discussion. Therefor, the majority of the media coverage of events to maintain the smooth flow and transparency to such an event.If ordinary people can be timely informed of the progress of events and the media should pay attention to the manifestation of social fairness in dealing with such events that makes everyone feels justice,the public networks will play the better role of social management only in real life.

\section{B. The traditional media is more likely to cause network media event}

The emergence of new media makes public accessing to select information becomes diversity. Many events exposed by blog,weibo, forums and other platforms. However, due to the traditional media irreplaceable affections, the traditional media reports confirmed that much easier to achieve consensus among netizens. Therefore, traditional medias and new medias combination to make news dissemination faster and more accurate, which have great significance for suppressing the occurrence of mass incidents.

\section{The network media Instrumentalization}

Network are lack of appropriate checks.People express their views on the network by the anonymity and timeliness. Among them are impulsive remarks, that will cause a series of negative effects on society, such as cyber attacks, human flesh search,and so on. These events brought people's lives a lot of consequences. However, the extent of involvement of users in the hot public opinion event occurred in 2013, you can see a lot full of enthusiasm and constructive comments appear. Except for some ulterior motives groups try to achieve their own ends, the majority of Internet users express their views on real eventsThere is a certain impact on social management. Network media is an effective way that ordinary people to participate in social management. Another point of view, the rise of online media means that the ordinary people need their rights as masters of the country.They just try to exercise their right to make their voices heard, which inevitably will have problems, so the governments and media have to guide. Meanwhile, with the continuous improvement of civic culture and political consciousness, the network will be increasingly high gold content of public opinion. The government should pay more attention to some of the public's views on hot issues of the country, listen to public opinion, so that people really get a sense of ownership.The government also solve the problem of the real wishes of the people. Through such a virtuous cycle,it makes the network of public opinion in a positive direction and varies network media airing national treasures, so that each person can truly participate in the process of governance in the country.

\section{REFERENCES}

[1] 2013 China Internet Public Opinion Analysis Report [EB/OL] [2014-01-09]http://yuqing.people.com.cn/n/2014/0318/c36439124662668.html

[2] Du Peng. Research of connotation of network group events based on cluster analysis[J]. Future and Development .2010 (8):38-43.

[3] Deng Xinmin. Guide on online public opinion and the opinion of the network[J]. Explore .2003 (5):78-80

[4] Lu Zhengwei. Analytical thinking of "network public opinion"[J]. SE dissemination .2008 (5):31-32

[5] Xu Jialin. Extreme emotional of network political opinion and the public political identity[J]. Marxism and the reality .2011 (3):174177

[6] Yang Pin, Li Tao, Zhao Kui.A method for quantitative analysis of network public opinion[J]. Computer Applications Research .2009 (3): 1066-1068,1078

[7] Zeng Runxi, Xu Xiaolin. Internet public opinion emergency warning systems, indicators and mechanisms[J]. Journal of Information .2009 (11):51,52-54.

[8] Guo Zhigang. Statistical analysis of social- spss software applications[M].Beijing. China Renmin University Press.1999

[9] Du Chundan,Zhou Lujun. Multivariate statistical analysis and applied research $[\mathrm{M}]$.Chengdu Southwest University of Finance and Economics Press.1994.

[10] Wang Lin. Export public opinion crisis[J]. Leadership Wencui .2011 (5):98-100

[11] Xie Jinlin. Social media network management new topic - foster a good cyber social psychology[J]. China Youth Research.2012(3).18-24

[12] Chen Hong,Shen Shenyi. Research of crisis information communication mechanism under the new media environment [J]. Modern Media.2011(3).121-125 